\title{
Influence of pathogen and focus of infection on procalcitonin values in sepsis patients with bacteremia or candidemia
}

\author{
Daniel O. Thomas-Rüddel ${ }^{1,2^{*}}$, Bernhard Poidinger ${ }^{1,2}$, Matthias Kott ${ }^{3}$, Manfred Weiss ${ }^{4}$, Konrad Reinhart ${ }^{1,2}$,
} Frank Bloos ${ }^{1,2}$ for the MEDUSA study group

\begin{abstract}
Background: This study aimed to evaluate the accuracy of procalcitonin (PCT) serum concentrations to diagnose Gram-negative bacteremia and the association of PCT serum concentrations with more specific pathogens and the focus of infection.

Methods: Secondary analysis of the prospectively collected patient-level dataset from a cluster randomized quality improvement trial was performed. The trial included sepsis patients with organ dysfunction treated in the participating intensive care units from 2011 to 2015. Test performance for the prediction of Gram-negative bacteremia was assessed by receiver operating curve analysis. Independent effects of specific pathogen groups and foci of infection on PCT concentrations were assessed by linear logistic regression models.

Results: Blood cultures (BC) and PCT concentrations had been taken in 4858 of 6561 documented patients. PCT was significantly higher in Gram-negative bacteremia compared to Gram-positive bacteremia or candidemia $(p<0.001)$. The area under the curve was 0.72 (95\% confidence interval 0.71-0.74) for the prediction of Gram-negative bacteremia compared to all other blood culture results including negative blood cultures. The optimized cutoff value was $10 \mathrm{ng} /$ $\mathrm{ml}$ (sensitivity 69\%, specificity 35\%). PCT differed significantly between specific groups of pathogens $(p<0.001)$ with highest concentrations in Escherichia coli, Streptococcus species and other Enterobacteriaceae. PCT was highest in urogenital followed by abdominal infection and lowest in respiratory infection $(p<0.001)$. In a linear regression model, Streptococci, E. coli and other Enterobacteriaceae detected from BC were associated with three times higher PCT values. Urogenital or abdominal foci of infection were associated with twofold increased PCT values independent of the pathogen.

Conclusions: Serum PCT concentrations are higher in patients with Gram-negative bacteremia than in patients with Gram-positive bacteremia or candidemia. However, the discriminatory power of this difference is too low to guide therapeutic decisions. Variations in PCT serum concentrations are not determined solely by Gram-negative or Grampositive bacteria but are also affected by distinct groups of pathogens and different foci of infection.
\end{abstract}

Trial registration: ClinicalTrials.gov, NCT01187134. Registered on 23 August 2010.

Keywords: Procalcitonin, Gram-negative bacteria, Gram-positive bacteria, Sepsis, Bacteremia, Focal infection

\footnotetext{
*Correspondence: Daniel.thomas@med.uni-jena.de

${ }^{1}$ Center for Sepsis Control and Care, Jena University Hospital, Jena, Germany

${ }^{2}$ Department of Anesthesiology and Intensive Care Medicine, Jena University

Hospital, Am Klinikum 1, 07747 Jena, Germany

Full list of author information is available at the end of the article
}

(c) The Author(s). 2018 Open Access This article is distributed under the terms of the Creative Commons Attribution 4.0 International License (http://creativecommons.org/licenses/by/4.0/), which permits unrestricted use, distribution, and reproduction in any medium, provided you give appropriate credit to the original author(s) and the source, provide a link to the Creative Commons license, and indicate if changes were made. The Creative Commons Public Domain Dedication waiver (http://creativecommons.org/publicdomain/zero/1.0/) applies to the data made available in this article, unless otherwise stated. 


\section{Background}

The production of procalcitonin (PCT), a prohormone of calcitonin, is upregulated in ubiquitous tissues in response to inflammatory stimuli including severe infection $[1,2]$. Even though elevated PCT serum concentrations are not exclusively specific to infections, PCT is considered among the best available biomarkers to diagnose sepsis [3] and can be helpful in reducing antibiotic exposure [4]. Beside initiation or discontinuation of antimicrobial therapy, the potential role of PCT in choosing specific antimicrobial substances without microbiological proof has been discussed $[5,6]$. Indeed, several studies have reported higher PCT levels in Gram-negative bacteremia compared to Gram-positive bacteremia [5, 7-10]. However, as interpretation of these studies is hampered by small sample size or limited clinical data, we analyzed data from a previous quality improvement trial in patients with severe sepsis or septic shock with a high number of patients [11]. The aim of this retrospective analysis was to evaluate the accuracy of PCT serum concentrations to predict Gramnegative bacteremia and to analyze whether specific pathogens and the focus of infection have a relevant influence on PCT serum concentrations.

\section{Methods}

\section{Study design}

This is a secondary analysis of the prospectively collected patient-level dataset from the MEDUSA study, a cluster randomized quality improvement trial aiming to improve early sepsis diagnosis and treatment in the participating hospitals by a multifaceted educational program [11]. The original trial was registered at ClinicalTrials.gov (NCT01187134) and was approved by the local ethics committees at each participating institution (see Additional file 1 for a complete list) and by the responsible state data protection boards.

\section{Study population}

Patients treated between July 1, 2011 and May 31, 2015 on the participating intensive care units (ICUs) with proven or suspected infection and at least one new infection-related organ dysfunction were eligible for inclusion. Patients were excluded if they had relevant limitations of therapy, were not treated on a participating ICU or had infection control measures started at another hospital before transfer.

\section{Data collection and laboratory diagnostics}

Data collection and definitions were as described previously $[11,12]$. Briefly, onset of severe sepsis or septic shock was defined as the time of first infection-related organ dysfunction. PCT measurements were performed in local laboratories using commercially available assays as part of routine care. Highest values of PCT and other laboratory parameters and most pathological values for vital signs but not changes over time were recorded within the first $24 \mathrm{~h}$ after the onset of severe sepsis as baseline data.

Blood cultures were drawn at severe sepsis onset before or after the start of antimicrobial therapy and processed and analyzed according to local standards. Blood culture results reporting typical contaminants (e.g., coagulasenegative Staphylococci, Corynebacterium species, Propionibacterium acnes and other skin colonizers) were carefully assessed by the treating physicians and if judged as contaminations were considered blood culture-negative in all analyses. Only isolates considered real pathogens were reported. Pathogens were grouped into Gram-positive bacteria, Gram-negative bacteria and candida. Pathogens were further divided into seven groups according to their phylogenetic relationship (Staphylococcus spp., Streptococcus spp., Enterococcus spp., Escherichia coli, Enterobacteriaceae other than E. coli, Pseudomonas spp. and Candida spp.). An eighth group was composed of all rarely detected pathogens that did not belong to one of the seven groups. The focus of infection was identified retrospectively by the treating physician taking into account all available clinical and microbiological data. For analysis, foci of infection were grouped into four categories (respiratory, abdominal, urogenital and bones/soft tissue).

\section{Data analysis}

Categorical data are expressed as absolute and relative frequencies, continuous data as median and interquartile range (IQR). Differences between groups were assessed by chi-square test or Kruskal-Wallis test. To assess the classification performance of PCT to predict Gram-negative bacteremia, receiver operating characteristic (ROC) curves with area under the curve (AUC) were calculated. In a second step, optimal cutoff values were determined by the Youden's index and test performance measures were calculated. In order to achieve normal distribution for further analysis, PCT was logarithmically transformed to the base of $10(\log \mathrm{PCT})$ and distribution was assessed by $\mathrm{P}-\mathrm{P}$ plots (see Additional file 2: Figure S1). To look for subgroups of pathogens and foci of infection distinguished by PCT values, one-way ANOVA with Scheffe and Dunnet's T3 post hoc comparison were performed based on logPCT.

We calculated linear logistic regression models with $\log \mathrm{PCT}$ as the dependent variable in order to assess for an independent effect of pathogen groups and foci of infection on PCT values. Specific groups of pathogens, foci of infection and interaction terms were stepwise included in the model. To account for potential confounding by antimicrobial therapy, the models were restricted to cases with blood cultures drawn before the start of a new antimicrobial therapy. In a further approach, potential confounders were added to the model by forward selection. 
$p \leq 0.05$ was considered statistically significant for all tests. Estimated values are presented with 95\% confidence intervals (CIs). All analyses were performed using IBM SPSS Statistics 23.0 and 25 (IBM, Armonk, NY, USA).

\section{Results}

\section{Patient population}

During the study period, 6561 patients with severe sepsis including septic shock from 40 hospitals were documented. Of these, 1266 had no blood cultures drawn at the time of sepsis onset and 691 had no PCT measured, resulting in 4858 patients with blood culture results and a PCT value available for analysis (Table 1).

Baseline and outcome clinical information depending on blood culture results is presented in Table 2. PCT concentrations were about three times higher in patients with positive blood cultures compared to negative or contaminated blood cultures $(p<0.001)$. Those with positive blood cultures showed a slightly higher severity of disease (SOFA score, serum lactate, urine output) but a similar proportion of patients meeting the criteria for septic shock. There was no difference in PCT values between patients with negative or contaminated blood cultures $(p=0.8)$.

\section{Prediction of Gram-negative bacteremia}

Blood cultures positive with Gram-negative pathogens were found in 815 patients only, while 948 patients were blood culture-positive with Gram-positive bacteria, solely, and 65 with candida spp. only. Those 159 patients with any mix of the three groups of pathogens were excluded from the analysis.

PCT concentrations in patients with Gram-negative bacteremia (26 ng/ml (7.7-63.1)) were distinctly higher than in patients with Gram-positive bacteremia $(7.1 \mathrm{ng} / \mathrm{ml}$ $(2.0-23.3))$ or candidemia $(4.7 \mathrm{ng} / \mathrm{ml}(1.9-13.7))(p<0$. 001) (Fig. 1a). There was no difference in C-reactive protein (CRP) concentrations $(p=0.7)$ or white blood cell count $(p=0.3)$ between the three groups.

The AUC in the ROC analysis was 0.69 (95\% confidence interval 0.67-0.72) for the differentiation of Gram-negative bacteremia from Gram-positive bacteremia or candidemia and was 0.72 (95\% CI 0.71-0.74) for the prediction of Gram-negative bacteremia compared to all other blood culture results including negative blood cultures (see
Additional file 2: Figure S2). Test performances for optimal cutoff values are presented in Table 3.

\section{Pathogen species, foci of infection and PCT concentrations}

Blood cultures positive with pathogens of a single group out of the predefined seven groups according to phylogenetic relationship and case numbers were found in 1643 patients (Table 3). We excluded 143 cases with pathogens which could not reasonably be grouped due to rarity and no close phylogenetic relationship to other pathogens. Another 207 patients with several groups of pathogens detected were excluded from the analysis. PCT concentrations differed significantly between the seven pathogen species $(p<$ 0.001), with highest concentrations in E. coli, Streptococcus spp. and other Enterobacteriaceae (Fig. 1b). There were no differences in PCT concentrations within the groups of pathogens except for Staphylococci and no distinct subsets could be identified from the different types of Staphylococci (Table 4).

Within the four infection categories, 3665 patients had a single focus of infection (Fig. 1c). We excluded 469 cases with unknown or rare focus of infection and 723 cases with more than one focus. There were significant differences in PCT concentrations between the different foci of infection $(p<0.001)$. PCT concentrations were highest in patients with urogenital infection, followed by abdominal infection, and lowest in respiratory infection (Fig. 1c).

A linear regression model was calculated based on 1146 cases with blood cultures positive with pathogens of a single group of pathogens and a single focus of infection using pathogen group and focus of infection as predictors of $\log \mathrm{PCT}$ (Table 5). Streptococci, E. coli and other Enterobacteriaceae were associated with three times higher PCT values than other pathogens in blood culture. Urogenital or abdominal foci of infection were associated with a twofold increased PCT concentration independent from the detected pathogen. There was no significant interaction effect between detected pathogen and focus of infection for the association with PCT concentrations.

A second linear regression model was calculated based on all cases showing that the detection of any pathogen except Pseudomonas spp. and Candida spp.

Table 1 Patient population regarding blood cultures and procalcitonin measurements

\begin{tabular}{lllll}
\hline Procalcitonin measured & \multicolumn{3}{l}{ Blood cultures drawn before or after first dose of antibiotics } & Tes, after \\
\cline { 2 - 4 } & No & Yes, before & 156 & 691 \\
\hline No & 254 & 281 & $\mathbf{1 7 0 1}$ & 5870 \\
Yes & 1012 & $\mathbf{3 1 5 7}$ & 1857 & 6561 \\
Total & 1266 & 3438 & $\mathbf{3}$ \\
\hline
\end{tabular}

In sum, 4858 patients (marked in bold) with blood cultures and procalcitonin taken at sepsis onset were available for analysis 
Table 2 Patient characteristics

\begin{tabular}{|c|c|c|c|c|}
\hline \multirow[t]{2}{*}{ Characteristic } & \multirow{2}{*}{$\begin{array}{l}\text { All patients } \\
(n=4858)\end{array}$} & \multicolumn{2}{|l|}{ Blood culture results } & \multirow[b]{2}{*}{$p$ value } \\
\hline & & $\begin{array}{l}\text { Negative or contamination } \\
(n=2875)\end{array}$ & $\begin{array}{l}\text { Positive with } \\
\text { pathogen } \\
(n=1983)\end{array}$ & \\
\hline Age (years) & $70(59-77)$ & $70(59-77)$ & $70(59-77)$ & 0.37 \\
\hline Sex (male) & $3060(63)$ & $1817(63)$ & $1243(63)$ & 0.71 \\
\hline Origin of infection & & & & $<0.001$ \\
\hline Community acquired & $2136(44.0)$ & $1172(39.6)$ & $964(46.5)$ & \\
\hline Nosocomial (ICU) & $1005(20.7)$ & $644(24.0)$ & $361(19.2)$ & \\
\hline Nosocomial (ward) & $1579(32.5)$ & $990(34.6)$ & $589(31.1)$ & \\
\hline Nosocomial (nursing home) & $138(2.8)$ & $69(1.8)$ & $69(3.2)$ & \\
\hline \multicolumn{5}{|l|}{ Focus of infection } \\
\hline Respiratory & $2035(41.9)$ & $1386(48.2)$ & $649(32.7)$ & $<0.001$ \\
\hline Abdominal & $1632(33.6)$ & $1040(36.2)$ & $592(29.9)$ & $<0.001$ \\
\hline Urogenital & $744(15.3)$ & $288(10.0)$ & $456(23.0)$ & $<0.001$ \\
\hline Bones/soft tissue & $565(11.6)$ & $282(9.8)$ & $283(14.3)$ & $<0.001$ \\
\hline Other & $673(13.9)$ & $300(10.4)$ & $373(18.8)$ & $<0.001$ \\
\hline \multicolumn{5}{|l|}{ Clinical data and scores } \\
\hline $\mathrm{PCT}(\mathrm{ng} / \mathrm{ml})$ & $6.4(1.7-25.6)$ & $4.1(1.2-15.5)$ & $12.6(3.3-41.9)$ & $<0.001$ \\
\hline CRP $(\mathrm{mg} / \mathrm{ml})$ & $208(116-301)$ & $196(111-293)$ & $219(125-310)$ & $<0.001$ \\
\hline WBC $\left(10^{9}\right)$ & $16.3(10.7-23.5)$ & $16.1(10.9-23.1)$ & $16.4(10.2-23.8)$ & 0.85 \\
\hline Leukopenia (WBC $\leq 4)$ & $545(11.2)$ & $281(9.8)$ & $264(13.3)$ & $<0.001$ \\
\hline Temperature $\left({ }^{\circ} \mathrm{C}\right)$ & $38.0(36.3-38.8)$ & $37.9(36.0-38.7)$ & $38.2(36.8-39.0)$ & $<0.001$ \\
\hline Lactate (mmol/l) & $2.7(1.6-5.0)$ & $2.6(1.5-4.7)$ & $3.0(1.7-5.5)$ & $<0.001$ \\
\hline Urine output (ml/24 h) & $1390(620-2350)$ & $1420(660-2430)$ & $1320(580-2300)$ & 0.02 \\
\hline SOFA & $9(7-12)$ & $9(7-11)$ & $10(7-12)$ & $<0.001$ \\
\hline Septic shock ${ }^{a}$ & $2714(55.9)$ & $1577(54.9)$ & $1137(57.3)$ & 0.09 \\
\hline \multicolumn{5}{|l|}{ Mortality } \\
\hline ICU mortality & 1485 (30.6) & $872(30.4)$ & $613(30.9)$ & 0.68 \\
\hline 28-Day mortality & $1562(33.0)$ & $888(31.7)$ & $674(34.8)$ & 0.03 \\
\hline Hospital mortality & $1861(38.4)$ & $1080(37.6)$ & 781 (39.4) & 0.21 \\
\hline
\end{tabular}

Data expressed as median (Q1-Q3) or number (percentage). $p$ values for comparison between negative and positive blood culture result groups $I C U$ intensive care unit, PCT procalcitonin, CRP C-reactive protein, WBC white blood cell count, SOFA Sequential Organ Failure Assessment Score ${ }^{\text {a }}$ Septic shock by Sepsis-3 criteria

in blood cultures was associated with higher PCT concentrations compared to negative blood cultures as the reference group (Table 6).

The effects of focus of infection on PCT serum concentrations stratified for the most frequent pathogens are shown in Fig. 2. Including potential confounders such as age, sex, origin of infection, type of ICU admission and disease severity (SOFA score, septic shock and lactate) as additional predictors (Table 7) showed very similar effects for pathogens and foci of infection. Also, restricting the analyses to cases that had blood cultures drawn before the start of a new antimicrobial therapy (see Additional file 2: Tables S1 and S2) did not result in major changes.

\section{Discussion}

The main finding of this study is confirmation that sepsis patients with proven Gram-negative bacteremia have significantly higher PCT concentrations than patients with Gram-positive bacteremia or candidemia. However, the present study demonstrates that the diagnostic accuracy is not sufficient to tailor empiric antimicrobial therapy based on PCT concentrations. In addition, for the first time in a large number of clinically wellcharacterized patients, an independent association of focus of infection and specific groups of pathogens with differences in PCT concentrations was detected. Urogenital or abdominal foci of infection were associated with two times higher PCT values, and Streptococci, E. 



Fig. 1 Initial PCT concentrations (ng/ml, median and IQR) associated with Gram stain (a) or type of pathogen (b) detected in blood culture drawn at sepsis onset, or associated with focus of infection (c). Significantly different $(p<0.001)$ in all three comparisons. $n$ denotes number of cases represented by each bar and superscript letters denote homogeneous subsets

coli and other Enterobacteriaceae detected from BC with three times higher PCT values.

The association of Gram-negative bacteremia with high PCT concentrations is in agreement with other studies performed in different patient populations [5, 8-10, 13-15]. However, absolute PCT concentrations reported in Gramnegative bacteremia differed considerably between these studies with median values ranging from $2.2 \mathrm{ng} / \mathrm{ml}$ [10] up to $39 \mathrm{ng} / \mathrm{ml}$ [8]. These differences are most likely attributable to different patient populations including patients with endocarditis [13] and febrile neutropenia [14]. Some larger patient cohorts were composed of all patients with blood culture results and corresponding PCT measurements available from intensive care units [5] or whole hospitals [9, 10] lacking clinical data including any confirmed diagnosis of infection or sepsis. Hence, comparability to our results is limited. Studies reporting patients diagnosed with clinical sepsis diagnosis and bacteremia, resembling our patient population, reported median PCT concentrations of $39 \mathrm{ng} /$ $\mathrm{ml}[8]$ and $27 \mathrm{ng} / \mathrm{ml}$ [16] in patients with Gram-negative bacteremia, being similar to the median PCT concentration of $26 \mathrm{ng} / \mathrm{ml}$ in 815 patients with Gram-negative bacteremia in our study.

As PCT expression is at least partly induced by inflammatory cytokines [17], differences in the pathogen specific signaling could explain the observed differences in PCT concentrations in the present study. Lipopolysaccharides (LPS), cell wall components of Gram-negative bacteria, are the prototypical class of pathogen-associated molecular patterns (PAMPs) and are recognized by cells of the innate immune system via toll-like receptor 4 (TLR4), while lipoteichoic acid (LTA), a cell wall component of Grampositive bacteria, is recognized by toll-like receptor 2 (TLR2) $[18,19]$. The intracellular signaling cascades of both receptors converge in part through common adaptor molecules on the same transcription factors, and both receptors are activated by components of whole Gram-negative and Gram-positive bacteria [18]. Nevertheless, the TLR4dominant activation by Gram-negative bacteria and the TLR2-dominant activation by Gram-positive bacteria result in a very different induction of several inflammatory cytokines $[18,20-22]$ and different gene expression patterns in leukocytes [20] in vitro. Higher levels of Interleukin-6 (IL6) $[23,24]$ and Interleukin-8 (IL-8) [24] have been reported in patients with Gram-negative bacteremia. These differences probably contribute to the observed differences in PCT response seen with Gram-negative or Gram-positive bacteremia.

To our knowledge, we are the first to describe significant differences in PCT concentrations for more specific groups of pathogens in a high number of clinically well-defined patients. Previous reports have been difficult to interpret due to the small number of cases for any but the most common pathogens $[5,16]$. In two large studies, one group reported nearly identical PCT concentrations for Staphylococci, Streptococci and Enterococci [10], and the other reported

Table 3 Test performance of procalcitonin for prediction of Gram-negative bacteremia

\begin{tabular}{|c|c|c|c|c|c|c|c|c|}
\hline Classification & Optimal cutoff (ng/ml) & SENS & SPEC & PPV & NPV & PLR & NLR & ACC \\
\hline $\begin{array}{l}\text { Gram-negative bacteremia vs } \\
\text { Gram-positive/candidemia }\end{array}$ & 17.5 & 0.59 & 0.70 & 0.61 & 0.68 & 1.98 & 0.59 & 0.65 \\
\hline $\begin{array}{l}\text { Gram-negative bacteremia vs } \\
\text { all other blood culture results }\end{array}$ & 10 & 0.69 & 0.65 & 0.33 & 0.9 & 1.97 & 0.47 & 0.66 \\
\hline
\end{tabular}

Optimal cutoff values derived from receiver operating characteristics by Youden's index and sensitivity (SENS), specificity (SPEC), positive predictive value (PPV), negative predictive value (NPV), positive likelihood ratio (PLR), negative likelihood ratio (NLR) and accuracy (ACC) calculated from the resulting $2 \times 2$ tables 
Table 4 Procalcitonin values associated with different pathogens

\begin{tabular}{|c|c|c|c|}
\hline Pathogen species detected from blood cultures & Number & $\mathrm{PCT}(\mathrm{IQR})$ & $p$ value \\
\hline Staphylococcus spp. & 574 & $5.6(1.9-17.7)$ & 0.015 \\
\hline Staphylococcus aureus, methicillin sensitive & 272 & $7.2(2.7-20.7)$ & \\
\hline Staphylococcus aureus, methicillin resistant & 58 & $4.7(1.4-10.6)$ & \\
\hline Coagulase-negative Staphylococci, methicillin sensitive & 151 & $5.2(1.4-16.1)$ & \\
\hline Coagulase-negative Staphylococci, methicillin resistant & 65 & $3.8(1.3-12.8)$ & \\
\hline Streptococcus spp. & 153 & $18.2(6.2-44.1)$ & 0.12 \\
\hline Streptococci, Group A, B, C or G & 59 & $18.2(8.4-47.3)$ & \\
\hline Streptococcus pneumoniae & 63 & $21.6(7-48.3)$ & \\
\hline Other Streptococci (Streptococcus mutans, other viridans Streptococci) & 26 & $6.8(3.6-44.1)$ & \\
\hline Enterococcus spp. & 128 & $6.8(2.2-27.8)$ & 0.5 \\
\hline Enterococcus faecalis & 41 & $8.7(2.1-54)$ & \\
\hline Enterococcus faecium & 71 & $6.7(2.3-25.3)$ & \\
\hline Vancomycin-resistant Enterococci & 7 & $1.9(0.5-99.3)$ & \\
\hline Escherichia coli & 436 & $26.8(9.8-70)$ & \\
\hline Enterobacteriaceae other than E. coli & 249 & $24.9(7.6-57.1)$ & 0.07 \\
\hline Enterobacter spp. & 38 & $21.1(7.6-56.8)$ & \\
\hline Klebsiella spp. & 123 & $21.5(6-49.7)$ & \\
\hline Proteus spp. & 47 & $46.8(9.1-97.6)$ & \\
\hline Serratia spp. & 20 & $12.1(6.5-42.4)$ & \\
\hline Citrobacter spp. & 9 & $37.8(15.1-113.1)$ & \\
\hline Enterobacteriaceae, other & 2 & $3.7(2.4-5)$ & \\
\hline Pseudomonas spp. & 35 & $5.9(2.1-28.4)$ & 0.4 \\
\hline Pseudomonas aeruginosa & 32 & $6.1(3.1-30.6)$ & \\
\hline Pseudomonas, other & 3 & $2.0(0.6-28.4)$ & \\
\hline Candida spp. & 68 & $4.7(2-14)$ & 0.7 \\
\hline Candida albicans & 57 & $5.3(2.1-15.3)$ & \\
\hline Candida, other & 37 & $6.5(2.2-17.4)$ & \\
\hline \multicolumn{4}{|l|}{ Rare pathogens } \\
\hline Listeria monocytogenes & 7 & $8.0(0.8-19.7)$ & \\
\hline Acinetobacter spp. & 7 & $5.8(0.9-39.0)$ & \\
\hline Haemophilus spp. & 4 & $29.9(17.3-36.6)$ & \\
\hline
\end{tabular}

Absolute numbers for defined groups of pathogens (in bold) and the pathogens composing them (reported only for cases with a single pathogen detected from blood culture). $p$ values for differences between pathogens within a group. Additionally, three most frequent of the rare pathogens reported at end of the table IQR interquartile range, $P C T$ procalcitonin

higher PCT concentrations in Streptococci than in other Gram-positive bacteria, but those PCT concentrations were still much lower than in the reported groups of Enterobacteriaceae [9]. Both studies had heterogeneous patient populations with extremely limited clinical information and did not assess the clinical relevance of the detected pathogens. A recent study on community-acquired pneumonia showed higher PCT concentrations associated with typical bacteria than with atypical bacteria [25]. One experimental study described several differences in intracellular signaling after TLR activation between Group A Streptococci, Staphylococcus aureus and E. coli, and speculated that this results in a lower inflammatory response in Streptococci [26]. Another in-vitro study compared cytokine production induced in cord blood cells by heat-killed Group B Streptococci, E. coli and Staphylococcus epidermidis, and found quite different response patterns with higher cytokine levels for E. coli and Streptococci [21]. The cytolytic toxin pneumolysin of Streptococcus pneumoniae is known to strongly activate TLR 4 [27], which may contribute to the high concentrations of PCT seen with Streptococcal bacteremia in our study.

The difference in the clinical course of sepsis depending on the focus of infection is widely acknowledged [28]. 
Table 5 Linear regression model limited to cases with one pathogen group and one focus of infection

\begin{tabular}{|c|c|c|c|c|}
\hline Variable & Regression coefficient & $95 \% \mathrm{Cl}$ & $p$ value & $\begin{array}{l}\text { Multiplier } \\
(95 \% \mathrm{Cl}) \\
\end{array}$ \\
\hline Staphylococcus spp. & 0.00 & $(-0.22$ to 0.21$)$ & 1.0 & $1.0(0.6-1.6)$ \\
\hline Streptococcus spp. & 0.50 & $(0.26-0.74)$ & $<0.001$ & $3.2(1.8-5.5)$ \\
\hline Enterococcus spp. & 0.06 & $(-0.18$ to 0.31$)$ & 0.6 & $1.1(0.7-2.0$ \\
\hline Escherichia coli & 0.50 & $(0.29-0.72)$ & $<0.001$ & $3.2(1.9-5.2$ \\
\hline Enterobacteriaceae, other & 0.49 & $(0.26-0.72)$ & $<0.001$ & $3.1(1.8-5.2$ \\
\hline Pseudomonas spp. & 0.04 & $(-0.3$ to 0.37$)$ & 0.8 & $1.1(0.5-2.3)$ \\
\hline Candida spp. & Reference & & & Reference \\
\hline Respiratory & -0.01 & $(-0.14$ to 0.12$)$ & 0.9 & $1(0.7-1.3)$ \\
\hline Abdominal & 0.27 & $(0.14-0.41)$ & $<0.001$ & $1.9(1.4-2.6$ \\
\hline Urogenital & 0.32 & $(0.17-0.47)$ & $<0.001$ & $2.1(1.5-3.0$ \\
\hline Bones/soft tissue & Reference & & & Reference \\
\hline Intercept & 0.63 & $(0.41-0.86)$ & $<0.001$ & $4.3(2.6-7.2)$ \\
\hline
\end{tabular}

Stepwise linear regression model for influence of pathogens in blood culture and focus of infection on logPCT ( $p<0.001$ for both steps) limited to 1146 cases with one pathogen group detected in blood culture and one focus of infection; adjusted $R^{2}=0.18$; effect of the interaction term not significant ( $p=0.13$ ) and it was omitted from final model

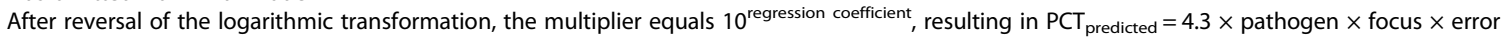

$\mathrm{Cl}$ confidence interval, PCT procalcitonin

Differences in mortality depending on the focus of infection have been reported previously [29]. To our knowledge, we are the first to systematically assess the association of different foci of infection in sepsis with measured PCT concentrations in ICU patients. One recent study investigating emergency room patients with clinical diagnosis of severe sepsis and septic shock and low PCT concentrations $(<0.25 \mathrm{ng} / \mathrm{ml})$ found a significant association of pneumonia with low PCT compared to abdominal sepsis, even after correcting for multiple factors

Table 6 Linear regression model for all cases

\begin{tabular}{|c|c|c|c|c|}
\hline Variable & Regressioncoefficient & $95 \% \mathrm{Cl}$ & $p$ value & $\begin{array}{l}\text { Multiplier } \\
(95 \% \text { Cl) }\end{array}$ \\
\hline Staphylococcus spp. & 0.13 & $(0.06-0.2)$ & $<0.001$ & $1.4(1.2-1.6)$ \\
\hline Streptococcus spp. & 0.59 & $(0.47-0.71)$ & $<0.001$ & $3.9(3.0-5.1)$ \\
\hline Enterococcus spp & 0.17 & $(0.03-0.29)$ & 0.01 & $1.5(1.1-2.0)$ \\
\hline Escherichia coli & 0.62 & $(0.54-0.7)$ & $<0.001$ & $4.2(3.5-5)$. \\
\hline Enterobacteriaceae, other & 0.56 & $(0.46-0.65)$ & $<0.001$ & $3.7(2.9-4.6)$ \\
\hline Pseudomonas spp. & 0.23 & $(-0.02$ to 0.47$)$ & 0.07 & $1.7(1.0-2.9)$ \\
\hline Candida spp. & 0.07 & $(-0.11$ to 0.24$)$ & 0.44 & $1.2(0.8-1.8)$ \\
\hline Several pathogens & 0.46 & $(0.36-0.56)$ & $<0.001$ & $2.9(2.3-3.7)$ \\
\hline Rare pathogens & 0.28 & $(0.16-0.4)$ & $<0.001$ & $1.9(1.5-2.6)$ \\
\hline No pathogen detected & Reference & & & Reference \\
\hline Respiratory & -0.24 & $(-0.32$ to -0.16$)$ & $<0.001$ & $0.6(0.5-0.7)$ \\
\hline Abdominal & 0.14 & $(0.06-0.22)$ & $<0.001$ & $1.5(1.3-1.8)$ \\
\hline Urogenital & 0.18 & $(0.08-0.27)$ & $<0.001$ & $1.6(1.3-2.0)$ \\
\hline Bones/soft tissue & -0.17 & $(-0.27$ to -0.07$)$ & $<0.001$ & $0.8(0.6-1.0)$ \\
\hline Several foci & -0.13 & $(-0.22$ to -0.04$)$ & $<0.001$ & $0.8(0.7-1.0)$ \\
\hline Other/unknown & Reference & & & Reference \\
\hline Intercept & 0.70 & $(0.62-0.77)$ & $<0.001$ & $4.5(3.9-5.3)$ \\
\hline
\end{tabular}

Stepwise linear regression for influence of pathogens in blood culture and focus of infection on logPCT ( $p<0.001$ for both steps) including all 4857 cases with PCT measurement and blood cultures taken; adjusted $R^{2}=0.15$; effect of the interaction term not significant $(p=0.47)$ and it was omitted from the final model

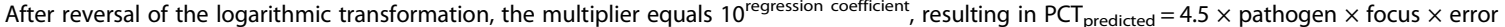
Cl confidence interval, PCT procalcitonin 


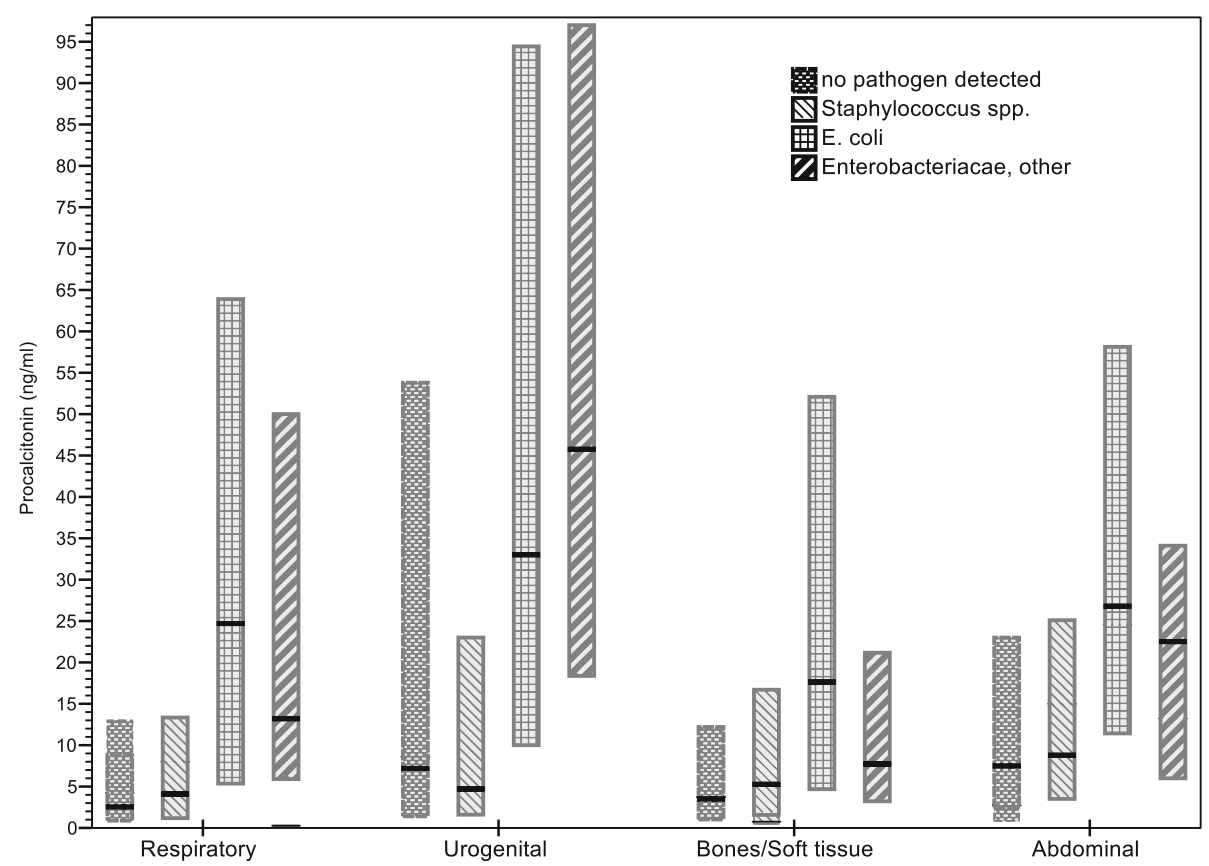

Fig. 2 Median and IQR of PCT concentrations associated with focus of infection in combination with most frequent blood culture results. Associations of focus and pathogens independent from each other (see Tables 5 and 6)

including bacteremia [30]. Such a difference in the PCT response might be explained by differences in the spectrum of pathogens depending on the focus of infection. However, the focus of infection and the underlying pathogen were independently associated with PCT concentrations in our multivariate analysis. Therefore, variations in the host response or in rates of bacteremia depending on the site of infection could be another explanation for differences in PCT concentrations. Indeed, bacteremia with a low bacterial load developed late in the course of experimental pneumonia [31]. Higher degrees of systemic bacterial load in bacteremia patients seemed to be associated with higher PCT concentrations [32]. An abdominal focus might be associated with a higher bacterial load as the lymphatic flow from the peritoneal cavity drains directly to the systemic circulation and the venous blood from the abdominal organs drains to the liver. To our knowledge there are no experimental or clinical data helping to support or discard those hypotheses. In mice, a gene array study comparing a pneumococcal pneumonia model and a polymicrobial fecal peritonitis model could not differentiate effects depending on sites of infection and pathogens [33].

Several authors have suggested that very high PCT concentrations are associated with Gram-negative bacteremia, and thus to tailor antimicrobial therapy $[5-10,15,16]$. However, according to our data, the clinical use of such an approach is limited by several factors. Firstly, a sepsis patient with only moderately elevated PCT concentrations has a low probability of Gram-negative bacteremia, but might still have a severe Gram-negative infection without bacteremia. Secondly, there is a large heterogeneity in PCT concentrations leaving a large area of overlap between Gram-negative bacteremia, Gram-positive bacteremia and candidemia. Although the reported AUCs for the differentiation of Gram-negative bacteremia from Gram-positive bacteremia were between 0.77 and 0.87 [5, 8, 9], we could not confirm such a high diagnostic accuracy as our analysis resulted in an AUC of 0.69 only. Furthermore, specificity was insufficient for clinical application. A diagnostic test guiding decisions about potentially lifesaving therapy needs to have a better diagnostic accuracy than that observed in our data in a high number of patients. Thirdly, as demonstrated in our study, the observed differences in PCT concentrations are associated with more specific groups of pathogens. We observed no differences in PCT concentrations between bacteremia with Staphylococcus spp., Enterococcus spp., Pseudomonas spp. and Candida spp., four groups of pathogens that would require very different empirical antimicrobial therapy.

Our analysis has several strengths and weaknesses. To our knowledge, this is the first study on the subject combining a large number of cases with a sufficient amount of clinical data in a fairly homogeneous group of sepsis patients treated in intensive care units. In contrast to previous studies, mostly based on laboratory data only, all of our patients had a clinical diagnosis of sepsis with organ dysfunction and the clinical relevance of any detected pathogen was assessed by the treating physicians. As this is 
Table 7 Linear regression model for all cases with forward selection of potential confounders

\begin{tabular}{|c|c|c|c|c|}
\hline Variable & $\begin{array}{l}\text { Regression } \\
\text { coefficient }\end{array}$ & $95 \% \mathrm{Cl}$ & $p$ value & $\begin{array}{l}\text { Multiplier } \\
(95 \% \text { Cl) }\end{array}$ \\
\hline Staphylococcus spp. & 0.11 & $(0.05-0.18)$ & $<.001$ & $1.3(1.1-1.5)$ \\
\hline Streptococcus spp. & 0.50 & $(0.39-0.62)$ & $<.001$ & $3.2(2.5-4.2)$ \\
\hline Enterococcus spp. & 0.14 & $(0.02-0.26)$ & 0.02 & $1.4(1.0-1.8)$ \\
\hline Escherichia coli & 0.52 & $(0.45-0.59)$ & $<.001$ & $3.3(2.8-3.9)$ \\
\hline Enterobacteriacae, other & 0.51 & $(0.42-0.6)$ & $<.001$ & $3.2(2.6-4.0)$ \\
\hline Pseudomonas spp. & 0.16 & $(-0.06$ to 0.39$)$ & 0.16 & $1.4(0.9-2.5)$ \\
\hline Candida spp. & 0.14 & $(-0.03$ to 0.31$)$ & 0.11 & $1.4(0.9-2.0)$ \\
\hline Several pathogens & 0.36 & $(0.26-0.46)$ & $<.001$ & $2.3(1.8-2.9)$ \\
\hline Rare pathogens & 0.20 & $(0.08-0.32)$ & $<.001$ & $1.6(1.2-2.1)$ \\
\hline No pathogen detected & Reference & & & Reference \\
\hline Respiratory & -0.24 & $(-0.31$ to -0.16$)$ & $<.001$ & $0.6(0.5-0.7)$ \\
\hline Abdominal & 0.09 & $(0.01-0.17)$ & $<.001$ & $1.2(1.0-1.5)$ \\
\hline Urogenital & 0.20 & $(0.11-0.3)$ & 0.02 & $1.6(1.3-2.0)$ \\
\hline Bones/soft tissue & -0.19 & $(-0.28$ to -0.1$)$ & $<.001$ & $0.6(0.5-0.8)$ \\
\hline Several foci & -0.10 & $(-0.19$ to -0.02$)$ & $<.001$ & $0.8(0.6-1.0)$ \\
\hline Other/unknown & Reference & & & Reference \\
\hline Male & 0.06 & $(0.02-0.1)$ & 0.002 & $1.1(1.0-1.3)$ \\
\hline Female & Reference & & & Reference \\
\hline Community acquired & 0.16 & $(0.11-0.2)$ & $<.001$ & $1.4(1.3-1.6)$ \\
\hline ICU acquired & -0.14 & $(-0.2$ to -0.09$)$ & $<.001$ & $0.7(0.6-0.8)$ \\
\hline Normal ward acquired & Reference & & & Reference \\
\hline Lactate per mmol// & 0.01 & $(0.01-0.02)$ & $<.001$ & $1.0(1.0-1.0)$ \\
\hline SOFA score per point & 0.03 & $(0.02-0.04)$ & $<.001$ & $1.1(1.0-1.1)$ \\
\hline Septic shock & 0.22 & $(0.18-0.27)$ & $<.001$ & $1.7(1.5-1.9)$ \\
\hline Intercept & 0.66 & $(0.57-0.74)$ & $<.001$ & $4.5(3.7-5.5)$ \\
\hline
\end{tabular}

General linear model for influence of pathogens in blood culture and focus of infection on logPCT ( $p<0.001$ for both factors) including all 3156 cases with PCT measurement and blood cultures taken before start of new antimicrobial therapy; additional potential confounders added by stepwise selection; age ( $p=0.3$ ) and type of ICU admission (0.14) were only ones not selected. Adjusted $R^{2}=0.24$; interaction terms not included in model

After reversal of the logarithmic transformation, the multiplier equals $10^{\text {regression coefficient, }}$, resulting in $\mathrm{PCT}_{\text {predicted }}=4.5 \times$ pathogen $\times$ focus $\times$ confounders $\times$ error

$\mathrm{Cl}$ confidence interval, ICU intensive care unit, PCT procalcitonin, SOFA Sequential Organ Failure Assessment Score

a secondary analysis of data from a multicenter quality improvement trial, the available information is limited. We have no information on how the focus of infection was diagnosed and which pathogens were detected from the focus of infection. Assessment of the blood culture results and the underlying infection was not confirmed by an independent review board.

\section{Conclusions}

Serum procalcitonin concentrations are higher in patients with Gram-negative bacteremia than in patients with Gram-positive bacteremia or candidemia. However, the discriminatory power of this difference is too low to guide therapeutic decisions. Variations in PCT serum concentrations are not determined by Gram-negative or Gram-positive bacteria per se, but by certain groups of pathogens and different foci of infection. Although PCT concentrations could give some additional information about the likelihood of distinct pathogens and foci of infection in sepsis patients, this information should be interpreted with caution and in due consideration with all available clinical information, and it can never replace a thorough microbiological work up and search for a focus of infection. However, it might reflect the degree of immune response to the underlying infection.

\section{Additional files}

Additional file 1: All involved ethical bodies with reference number of the vote (PDF $45 \mathrm{~kb}$ )

Additional file 2: Figure S1. P-P plots of PCT and $\log P C T$. Figure S2. AUC plots for ROC analyses. Tables S1 and S2. Regression models limited to cases with blood cultures taken before start of antimicrobial therapy (DOC $215 \mathrm{~kb}$ ) 


\section{Abbreviations}

ANOVA: Analysis of variance; AUC: Area under the curve; Cl: Confidence interval; CRP: C-reactive protein; ICU: Intensive care unit; IQR: Interquartile range; PCT: Procalcitonin; ROC: Receiver operating characteristic; SOFA: Sequential Organ Failure Assessment Score; spp:: Species pluralis; WBC: White blood cell count

\section{Acknowledgements}

A complete list of all institutions and investigators participating in the collection of the used dataset has been provided previously [11]. Some preliminary analyses were presented as an abstract at the Weimar Sepsis Update 2015 [34].

\section{Funding}

The original trial (NCT01187134) whose dataset was analyzed was funded by the German Federal Ministry of Education and Research via the Center for Sepsis Control and Care integrated research and treatment center (FKZ 01EO1002). The funding body had no part in the design, analysis and interpretation of data in the presented manuscript.

\section{Availability of data and materials}

The datasets analyzed during the current study are available from the corresponding author on reasonable request.

\section{Authors' contributions}

DOT-R and BP planned the secondary analysis presented in the manuscript. DOT-R conducted the statistical analysis. All authors participated in the interpretation of results. DOT-R drafted the manuscript and all authors revised it critically for important intellectual content. KR and FB designed, organized and led the cluster randomized trial whose dataset was analyzed. All authors participated in the original data collection and gave final consent of the version to be published. All authors read and approved the final manuscript.

\section{Ethics approval and consent to participate}

The original trial whose dataset was analyzed was approved by the local ethics committees at each participating institution and by the responsible state data protection boards. The need for informed consent was waived by all committees and data protection boards. The main vote was by the ethics committee of the University Hospital Jena (2910-08/10). A list of all involved ethical bodies is supplied as Additional file 1. No ethics approval was necessary for this secondary analysis.

\section{Competing interests}

The authors declare that they have no competing interests.

\section{Publisher's Note}

Springer Nature remains neutral with regard to jurisdictional claims in published maps and institutional affiliations.

\section{Author details}

${ }^{1}$ Center for Sepsis Control and Care, Jena University Hospital, Jena, Germany. ${ }^{2}$ Department of Anesthesiology and Intensive Care Medicine, Jena University Hospital, Am Klinikum 1, 07747 Jena, Germany. ${ }^{3}$ Department of Anaesthesiology and Intensive Care Medicine, University Hospital Schleswig-Holstein, Campus Kiel, Kiel, Germany. ${ }^{4}$ Clinic of Anaesthesiology, University Hospital Medical School, Ulm, Germany.

\section{Received: 25 October 2017 Accepted: 23 April 2018}

\section{Published online: 13 May 2018}

\section{References}

1. Maruna P, Nedelnikova K, Gurlich R. Physiology and genetics of procalcitonin. Physiol Res. 2000;49(Suppl 1):S57-61.

2. Meisner M. Pathobiochemistry and clinical use of procalcitonin. Clin Chim Acta. 2002;323(1-2):17-29.

3. Wacker C, Prkno A, Brunkhorst FM, Schlattmann P. Procalcitonin as a diagnostic marker for sepsis: a systematic review and meta-analysis. Lancet Infect Dis. 2013;13(5):426-35.

4. Rhodes A, Evans LE, Alhazzani W, Levy MM, Antonelli M, Ferrer R, Kumar A Sevransky JE, Sprung CL, Nunnally ME, et al. Surviving Sepsis Campaign:
International Guidelines for Management of Sepsis and Septic Shock: 2016. Intensive Care Med. 2017:43(3):304-77.

5. Brodska H, Malickova K, Adamkova V, Benakova H, Stastna MM, Zima T. Significantly higher procalcitonin levels could differentiate Gram-negative sepsis from Gram-positive and fungal sepsis. Clin Exp Med. 2012;13(3):165-70.

6. Moyer MW. New biomarkers sought for improving sepsis management and care. Nat Med. 2012;18(7):999

7. Beloborodova NV, Vostrikova T, Chernevskaia EA. Etiology of postoperative bacteremias in an intensive care unit: an association with the level of procalcitonin. Anesteziol Reanimatol. 2008;4:22-7.

8. Charles PE, Ladoire S, Aho S, Quenot JP, Doise JM, Prin S, Olsson NO, Blettery B. Serum procalcitonin elevation in critically ill patients at the onset of bacteremia caused by either Gram negative or Gram positive bacteria. BMC Infect Dis. 2008:8:38.

9. Leli C, Ferranti M, Moretti A, Al Dhahab ZS, Cenci E, Mencacci A Procalcitonin levels in gram-positive, gram-negative, and fungal bloodstream infections. Dis Markers. 2015:2015:701480.

10. Oussalah A, Ferrand J, Filhine-Tresarrieu P, Aissa N, Aimone-Gastin I, Namour F, Garcia M, Lozniewski A, Gueant JL. Diagnostic accuracy of procalcitonin for predicting blood culture results in patients with suspected bloodstream infection: an observational study of 35,343 consecutive patients (a STROBEcompliant article). Medicine (Baltimore). 2015;94(44):e1774.

11. Bloos F, Ruddel H, Thomas-Ruddel D, Schwarzkopf D, Pausch C, Harbarth S, Schreiber T, Grundling M, Marshall J, Simon P, et al. Effect of a multifaceted educational intervention for anti-infectious measures on sepsis mortality: a cluster randomized trial. Intensive Care Med. 2017;43(11):1602-12.

12. Bloos F, Thomas-Ruddel D, Ruddel H, Engel C, Schwarzkopf D, Marshall JC, Harbarth S, Simon P, Riessen R, Keh D, et al. Impact of compliance with infection management guidelines on outcome in patients with severe sepsis: a prospective observational multi-center study. Crit Care. 2014;18(2):R42.

13. Kocazeybek B, Kucukoglu S, Oner YA. Procalcitonin and C-reactive protein in infective endocarditis: correlation with etiology and prognosis. Chemotherapy. 2003:49(1-2):76-84

14. Koivula I, Hamalainen S, Jantunen E, Pulkki K, Kuittinen T, Nousiainen T, Juutilainen A. Elevated procalcitonin predicts Gram-negative sepsis in haematological patients with febrile neutropenia. Scand J Infect Dis. 2011;43(6-7):471-8.

15. Nakajima A, Yazawa J, Sugiki D, Mizuguchi M, Sagara H, Fujisiro M, Shibazaki M, Hitani A, To M, Haruki K. Clinical utility of procalcitonin as a marker of sepsis: a potential predictor of causative pathogens. Intern Med. 2014;53(14): 1497-503.

16. Guo SY, Zhou Y, Hu QF, Yao J, Wang H. Procalcitonin is a marker of Gramnegative bacteremia in patients with sepsis. Am J Med Sci. 2015;349(6):499-504

17. Matwiyoff GN, Prahl JD, Miller RJ, Carmichael JJ, Amundson DE, Seda G, Daheshia M. Immune regulation of procalcitonin: a biomarker and mediator of infection. Inflamm Res. 2012:61(5):401-9.

18. Gao H, Evans TW, Finney SJ. Bench-to-bedside review: sepsis, severe sepsis and septic shock-does the nature of the infecting organism matter? Crit Care. 2008;12(3):213

19. Leaver S, Burke Gaffney A, Evans TW. Gram-positive and Gram-negative sepsis: two disease entities? In: Vincent J-L, editor. Intensive Care Medicine: Annual Update 2008. New York: Springer; 2008. p. 395-403.

20. Feezor RJ, Oberholzer C, Baker HV, Novick D, Rubinstein M, Moldawer LL, Pribble J, Souza S, Dinarello CA, Ertel W, et al. Molecular characterization of the acute inflammatory response to infections with gram-negative versus gram-positive bacteria. Infect Immun. 2003;71(10):5803-13.

21. Mohamed MA, Cunningham-Rundles S, Dean CR, Hammad TA, Nesin M. Levels of pro-inflammatory cytokines produced from cord blood in-vitro are pathogen dependent and increased in comparison to adult controls. Cytokine. 2007;39(3):171-7.

22. Re F, Strominger JL. Toll-like receptor 2 (TLR2) and TLR4 differentially activate human dendritic cells. J Biol Chem. 2001;276(40):37692-9.

23. Abe R, Oda S, Sadahiro T, Nakamura M, Hirayama Y, Tateishi Y, Shinozaki K, Hirasawa H. Gram-negative bacteremia induces greater magnitude of inflammatory response than Gram-positive bacteremia. Crit Care. 2010;14(2):R27.

24. Prat C, Dominguez J, Andreo F, Blanco S, Pallares A, Cuchillo F, Ramil C, Ruiz-Manzano J, Ausina V. Procalcitonin and neopterin correlation with aetiology and severity of pneumonia. J Inf Secur. 2006;52(3):169-77.

25. Self WH, Balk RA, Grijalva CG, Williams DJ, Zhu Y, Anderson EJ, Waterer GW, Courtney DM, Bramley AM, Trabue C, et al. Procalcitonin as a marker of etiology in adults hospitalized with community-acquired pneumonia. Clin Infect Dis. 2017;65(2):183-90. 
26. Wu S, Ma C, Gao X, Zhang L, Miao Q, Li M, Li W, Song X, Wang X, Liu J, et al. Group A Streptococcus induces less p65 nuclear translocation and nonclassical nuclear factor kappa B activation in macrophages, which possibly leads to a weaker inflammatory response. Int J Infect Dis. 2016:44:50-60.

27. Malley R, Henneke P, Morse SC, Cieslewicz MJ, Lipsitch M, Thompson CM, Kurt-Jones E, Paton JC, Wessels MR, Golenbock DT. Recognition of pneumolysin by Toll-like receptor 4 confers resistance to pneumococcal infection. Proc Natl Acad Sci U S A. 2003;100(4):1966-71.

28. Vincent IL, Opal S, Torres A, Bonten M, Cohen J, Wunderink R. The PIRO concept: I is for infection. Crit Care. 2003;7(3):252-5.

29. Osborn TM, Phillips G, Lemeshow S, Townsend S, Schorr CA, Levy MM, Dellinger RP. Sepsis severity score: an internationally derived scoring system from the surviving sepsis campaign database. Crit Care Med. 2014;42(9):1969-76.

30. Choe EA, Shin TG, Jo IJ, Hwang SY, Lee TR, Cha WC, Sim MS. The prevalence and clinical significance of low procalcitonin levels among patients with severe sepsis or septic shock in the emergency department. Shock. 2016; 46(1):37-43.

31. Andonegui G, Goring K, Liu D, McCafferty DM, Winston BW. Characterization of S. pneumoniae pneumonia-induced multiple organ dysfunction syndrome: an experimental mouse model of gram-positive sepsis. Shock. 2009:31(4):423-8.

32. van Nieuwkoop C, Bonten TN, van't Wout JW, Kuijper EJ, Groeneveld GH, Becker MJ, Koster T, Wattel-Louis GH, Delfos NM, Ablij HC, et al. Procalcitonin reflects bacteremia and bacterial load in urosepsis syndrome: a prospective observational study. Crit Care. 2010;14(6):R206.

33. Weber M. Transkriptomik der Inflammation an der Maus: die Lunge als Ausgangsorgan und als Zielorgan der Sepsis. Jena: Friedrich Schiller University; 2010

34. Thomas-Rueddel DO, Poidinger B, Eiche J, Jelschen F, Kott M, Weiss M, Reinhart K, Bloos F. Influence of pathogen and focus of infection on procalcitonin values in bacteremic severe sepsis. Infection. 2015;43:538-9.

\section{Ready to submit your research? Choose BMC and benefit from:}

- fast, convenient online submission

- thorough peer review by experienced researchers in your field

- rapid publication on acceptance

- support for research data, including large and complex data types

- gold Open Access which fosters wider collaboration and increased citations - maximum visibility for your research: over $100 \mathrm{M}$ website views per year

At BMC, research is always in progress.

Learn more biomedcentral.com/submissions 